\title{
Rationality and Validity of ITKs on Tribal Medicine and Tribal Foods of Tribal Farmers in Telangana of Andhra Pradesh, India
}

\author{
N. Praveen* and I. Sreenivasa Rao \\ Department of Agricultural Extension, College of Agriculture, Professor Jayashankar \\ Telangana State Agricultural University, Hyderabad - 500030, Telangana, India \\ *Corresponding author
}

\section{A B S T R A C T}

\begin{tabular}{|l|}
\hline Key w or d s \\
Rationality, \\
Validity, ITKs, \\
Tribal medicine \\
\hline Article Info \\
\hline $\begin{array}{l}\text { Accepted: } \\
\text { 20 September } 2018 \\
\text { Available Online: } \\
\text { 10 October } 2018\end{array}$ \\
\hline
\end{tabular}

This study was conducted in Adilabad, Khammam and Warangal districts of Telangana. Ex post-facto research design was followed in this study, since different variables chosen for the study had already occurred. An effort was made to document the indigenous technology of tribal farmers. For testing the rationality of the ITKs, a questionnaire containing lists of ITKs was prepared and exposed to the scientists for judging their rationality and validity on a three point scale wherein, 3 is rational, 2 undecided and 1 is irrational. The mean score was calculated by summing the scores overall and divided by the number of judges for a given item and if it is more than two then the item was considered as rational and less than two was considered as irrational. For validity, the scientists were asked to find out the valid ITKs among rational ITKs which were validated, tested and verified on the basis of research. Out of 29 ITKs on Tribal foods only 14 ITKs (78.04\%) were found rational and the remaining 9 ITKs $(21.96 \%)$ were found irrational, whereas. On tribal medicines it was found that 7 ITKs $(70.00 \%)$ were judged rational and 3 ITKs (30.0\%) were judged not rational.

\section{Introduction}

Tribals in course of their close interactions with nature and natural resources have to make certain decisions to solve the problems they encounter in their day to day life while managing the land and environmental resources for survival. Compelling situations motivate them to generate knowledge out of necessity. Therefore, indigenous knowledge so developed is based on necessities, curiosity and observations of ethnic groups to mitigate the immediate situations. Tribals in the districts are mostly below poverty line and alienated from development and basically survive on subsistent agriculture which is primitive in nature.

Tribals are generally steeped with a number of superstitious and primitive beliefs related to crop production and protection practices. Some of the beliefs play a vital role in deciding the sustainability of a technology to reduce the cost of cultivation and to propagate eco-friendly agriculture (Sundaramari and Ranganathan, 2003). According to Haverkort (1995) ITK is the actual knowledge of a given population that reflects the experiences based 
on tradition and includes more recent experiences with modern techniques. ITKs are broad based, ecologically sound, environmentally safe, socially acceptable and economically resilient. Identifying, documenting and incorporating the indigenous knowledge systems into agriculture extension organizations is essential to achieve sustainable agriculture development (Rajasekharan, 1993). Hence, an attempt has been made in this study with the following specific objectives.

To identify and document the indigenous agricultural practices of tribal farmers in Telngana region of Andhra Pradesh.

To ascertain the scientific rationality and validity of ITKs on Tribal foods and Tribal medicine of Tribal Farmers in Telangana.

This can create favourable attitude towards rational ITKs for quick dissemination of technology and increase the area under cultivation.

\section{Materials and Methods}

The study was conducted by adopting an expostfacto research design method to study the rationality and validity of ITKs towards indigenous agricultural practices. The study was conducted in Adilabad, Khammam and Warangal districts of Telangana. From each district four mandals were selected and from each mandal three villages were selected and from each village six farmers were selected for this study by following random sampling method. Thus the study represents 3 districts, 12 mandals, 36 villages and 216 respondents. For testing the rationality of the ITKs, questionnaires containing different lists of ITKs pertaining to Plant Protection and Postharvest technology were prepared and exposed to the scientists for judging their rationality and validity by giving three point scale viz., a score of 3 for rational, 2 for undecided and 1 for not rationale. The mean score was calculated by summing the overall scores and divided by the number of judges for a given item and if it was more than two then the item was considered as rational and less than two was considered as irrational. For validity, the scientist respondents were asked to find out the valid ITKs among rational ITKs which were validated, tested and verified on the basis of research in the State. Out of 41 ITKs on plant protection and post-harvest technology, 32 ITKs $(78.04 \%)$ were found rational and remaining 9 ITKs $(21.96 \%)$ were found irrational. And 30 ITKs were found valid.

\section{Results and Discussion}

It could be observed from the above Table 1 out of 29 ITKs in tribal foods and nutrition, 23 ITKs $(79.31 \%)$ were judged rational by the scientists and 6 ITKs $(20.69 \%)$ were judged not rational whereas 14 ITKs were found valid.

The ITK No.1 \& 2 were found rational and valid because of the practices followed which indicate boiling of tubers and roots by the tribal for consumption were highly nutritious and do not contain any harmful substance.

The ITK No 7 and 8 were to be found to be rational and valid because the porridge prepared from ragi powder is highly nutritious and good for all age groups and it is a common practice by almost all the tribals.

The ITK No 6, 11, 12 and 16 were to be found to be rational and valid except ITK No 6 and 9 were found rational and not valid.

The tubers, roots, wild fruits collected from the forest were used in preparation of curry and chutney for daily use. These are all age old practices adopted by them from generation to generation, but still validation is not there. 
Table.1 Rationality and Validity ITKs on Tribal foods

\begin{tabular}{|c|c|c|c|c|}
\hline $\begin{array}{l}\text { ITK } \\
\text { No }\end{array}$ & Indigenous Technical Knowledge (ITKs) & $\begin{array}{l}\text { Mean } \\
\text { score }\end{array}$ & $\begin{array}{l}\text { Ratio } \\
\text { nality }\end{array}$ & Validity \\
\hline 1 & $\begin{array}{l}\text { Roots and tubers of Konda mula (Ipomea batata) often eaten by } \\
\text { the tribals by boiling for } 15-20 \text { minutes }\end{array}$ & 2.34 & $\mathrm{R}$ & $\mathrm{V}$ \\
\hline 2 & $\begin{array}{l}\text { Casava roots soaked and boiled for } 15-20 \text { minutes then peeled } \\
\text { and eaten with salt or sugar. }\end{array}$ & 2.13 & $\mathrm{R}$ & $\mathrm{V}$ \\
\hline 3 & $\begin{array}{l}\text { Fruits of (Diospyros and Ziziphus mauritiana) are consumed by } \\
\text { tribals when ripen. }\end{array}$ & 1.95 & $\mathrm{R}$ & $\mathrm{V}$ \\
\hline 4 & $\begin{array}{l}\text { Flowers of (Cassia auriuculata, Cassia fistula, Abtulon } \\
\text { indicum) are used as vegetables, }\end{array}$ & 2.41 & $\mathrm{R}$ & NV \\
\hline 5 & $\begin{array}{l}\text { Raw tubers of Konda mula (Ipomea batata) roasted in fire for } \\
\text { five minutes until brown colour obtained and consumed after } \\
\text { peeling }\end{array}$ & 2.34 & IR & - \\
\hline 6 & The tuber and roots of casava are crushed boiled and consumed & 2.75 & $\mathrm{R}$ & NV \\
\hline 7 & $\begin{array}{l}\text { Tribal prepare porridge by putting ragi powder in boiling water } \\
\text { by stirring } 20 \text { minutes and then consumed }\end{array}$ & 2.96 & $\mathrm{R}$ & V \\
\hline 8 & $\begin{array}{l}\text { Ragi cake is prepared by the tribals by adding ragi powder in } \\
\text { boiling water with coconut grates }+ \text { groundnut pieces }+ \text { jaggery } \\
\text { until it becomes cake for consumption }\end{array}$ & 2.89 & $\mathrm{R}$ & $\mathrm{V}$ \\
\hline 9 & $\begin{array}{l}\text { Rhizomes and tubers collected from the forest are washed kept } \\
\text { for sometime in turmeric powder for removing bitterness and } \\
\text { harmful content }\end{array}$ & 2.68 & $\mathrm{R}$ & NV \\
\hline 10 & $\begin{array}{l}\text { Roots of (Butea monosperma) modugu is crushed and used as } \\
\text { flour. }\end{array}$ & 1.78 & IR & - \\
\hline 11 & $\begin{array}{l}\text { Fruits of Capparis, Solanum xanthium) are used in curry } \\
\text { preparation by the tribal }\end{array}$ & 2.76 & $\mathrm{R}$ & V \\
\hline 12 & $\begin{array}{l}\text { Fruits of Madhuca indica and dried mahua flowers boiled with } \\
\text { tamarind seeds (Tamarindus indicus) as an important tribal diet }\end{array}$ & 2.19 & $\mathrm{R}$ & V \\
\hline 13 & $\begin{array}{l}\text { Leaves of Achrathes aspera, Amaranthus tricholor are used as } \\
\text { leafy vegetables }\end{array}$ & 2.85 & $\mathrm{R}$ & V \\
\hline 14 & $\begin{array}{l}\text { Crushed stem of talati (Cleome gynanadra) plant mixed with } \\
\text { turmeric and salt and consumed by the tribal. }\end{array}$ & 2.98 & $\mathrm{R}$ & NV \\
\hline 15 & $\begin{array}{l}\text { Tuber roots Compegia bulbosa (Roxb) are boiled and consumed } \\
\text { by the tribal. }\end{array}$ & 3.01 & $\mathrm{R}$ & V \\
\hline 16 & $\begin{array}{l}\text { Tender stem of Kundeti kommulu (Andrographis paniculata) } \\
\text { used as curry or chutney }\end{array}$ & 1.84 & IR & - \\
\hline 17 & $\begin{array}{l}\text { The tubers of adavi kiska (Dioscorea tomentosa) cut in to } \\
\text { pieces soaked in running water for } 3 \text { days then boiled and } \\
\text { consumed. }\end{array}$ & 1.17 & IR & - \\
\hline 18 & $\begin{array}{l}\text { Leaves of palateega roots and bark are crushed and the powder } \\
\text { made from it is used as coffee powder }\end{array}$ & 2.01 & IR & NV \\
\hline 19 & $\begin{array}{l}\text { The unripe fruits of pativratha (Mucuna Provens) is roasted and } \\
\text { consumed and also used as curry }\end{array}$ & 2.82 & $\mathrm{R}$ & NV \\
\hline
\end{tabular}




\begin{tabular}{|c|c|c|c|c|}
\hline 20 & Leafs of nagali kurra, ponnagantikurra is used for making curry. & 2.86 & $\mathrm{R}$ & $\mathrm{V}$ \\
\hline 21 & $\begin{array}{l}\text { Stem portion of Moulya (Caraluma attenta) is consumed by } \\
\text { boiling and making curry }\end{array}$ & 2.65 & $\mathrm{R}$ & NV \\
\hline 22 & $\begin{array}{l}\text { The flour prepared from maize and sorghum are consumed by } \\
\text { preparing porridge }\end{array}$ & 2.97 & $\mathrm{R}$ & V \\
\hline 23 & $\begin{array}{l}\text { Fruit of Dossana (Hibiscus rosasinesis) and wild amla (Emblica } \\
\text { officinalis) is consumed by making pickles and direct } \\
\text { consumption for health purpose. }\end{array}$ & 2.94 & $\mathrm{R}$ & $\mathrm{V}$ \\
\hline 24 & $\begin{array}{l}\text { Ippapuvu (Mahua latifolia) is used for cooking and } \\
\text { consumption. }\end{array}$ & 2.67 & $\mathrm{R}$ & NV \\
\hline 25 & $\begin{array}{l}\text { Ippapuvu (Mahua latifoilia) collected from the forest are } \\
\text { fermented for } 24 \text { hours for alcohol preparation for consumption. }\end{array}$ & 2.02 & $\mathrm{R}$ & $\mathrm{NV}$ \\
\hline 26 & $\begin{array}{l}\text { Chella ginjalu seeds collected from the forest placed in the } \\
\text { water for removal of turbidity in water }\end{array}$ & 1.91 & $\mathrm{R}$ & V \\
\hline 27 & $\begin{array}{l}\text { The Bajra and ragi is powder and java is prepared by mixing } \\
\text { with hot water which is highly nutritious. }\end{array}$ & 2.58 & $\mathrm{R}$ & $\mathrm{V}$ \\
\hline 28 & $\begin{array}{l}\text { Poda tiga leaves and roots are crushed and used as coffee } \\
\text { powder }\end{array}$ & 1.41 & IR & - \\
\hline & The boiled rice water called ganji is consumed by the tribals & 2.83 & $\mathrm{R}$ & $\mathrm{V}$ \\
\hline
\end{tabular}

Table.2 Rationality and Validity of ITKS on Tribal medicine

\begin{tabular}{|c|l|c|c|c|}
\hline ITK & \multicolumn{1}{|c|}{ Indigenous Technical Knowledge (ITKs) } & $\begin{array}{c}\text { Mean } \\
\text { score }\end{array}$ & $\begin{array}{c}\text { Ratio- } \\
\text { nality }\end{array}$ & $\begin{array}{c}\text { Validi } \\
\text { ty }\end{array}$ \\
\hline $\mathbf{1}$ & $\begin{array}{l}\text { Tribals use decoction from root tubers of Asparagus } \\
\text { racemosus used as anti septic agent }\end{array}$ & 2.67 & $\mathrm{R}$ & $\mathrm{V}$ \\
\hline $\mathbf{2}$ & $\begin{array}{l}\text { For headache they make the paste of (Achranthus aspera) } \\
\text { with a pinch of camphor which is applied on fore head }\end{array}$ & 2.02 & $\mathrm{R}$ & $\mathrm{V}$ \\
\hline $\mathbf{3}$ & $\begin{array}{l}\text { For indigestion tribal use coriander seed powder with a pinch } \\
\text { of salt are given on empty stomach }\end{array}$ & 1.91 & $\mathrm{IR}$ & - \\
\hline $\mathbf{4}$ & $\begin{array}{l}\text { For eye infection the juice extracted Trychosporium, lime or } \\
\text { onion or fresh turmeric is dropped in the eyes }\end{array}$ & 2.58 & $\mathrm{R}$ & $\mathrm{NV}$ \\
\hline $\mathbf{5}$ & $\begin{array}{l}\text { A paste made from Cuscuta refloxa Roxb plant is applied on } \\
\text { the stomach for liver disorder }\end{array}$ & 1.41 & $\mathrm{IR}$ & - \\
\hline $\mathbf{6}$ & $\begin{array}{l}\text { Decotion made from Ginger, coriander, fennel, black pepper, } \\
\text { mustard seeds mixed in equal proportion are given for } \\
\text { labouring mother to hasten delivery pains. }\end{array}$ & 1.91 & $\mathrm{IR}$ & - \\
\hline $\mathbf{7}$ & $\begin{array}{l}\text { After delivering a decotion or extract prepared from root of } \\
\text { Tephrosia purpurea to clean the uterus to ensure complete } \\
\text { discharge of placenta }\end{array}$ & 2.85 & $\mathrm{R}$ & - \\
\hline $\mathbf{8}$ & $\begin{array}{l}\text { Tribals use garlic bulb (Allium sativum) and dry ginger as } \\
\text { decoction as an antiseptic agent }\end{array}$ & 2.96 & $\mathrm{R}$ & $\mathrm{V}$ \\
\hline $\mathbf{9}$ & $\begin{array}{l}\text { The tribals use latex of calotrophis, bark of Acacia sp root of } \\
\text { Achranthes aspera are applied for tooth ache and infection }\end{array}$ & 2.87 & $\mathrm{R}$ & $\mathrm{V}$ \\
\hline $\mathbf{1 0}$ & \begin{tabular}{l} 
Uttareni leafs and roots are used for dental problems \\
\hline
\end{tabular} & 2.69 & $\mathrm{R}$ & $\mathrm{V}$ \\
\hline
\end{tabular}


The ITK No 9 and 13 were found rational and valid except ITK No 9 which is found not valid because the rhizomes collected from the forest is kept in turmeric powder to remove bitterness and it is ready for preparing chutney and curry and the leaves collected from uthareni and Amaranthus are used as leafy vegetable.

The ITK No.3, 4 and 23 were judged rational and valid because, the edible portions of the fruits are consumed by the tribals when ripened as food. The flowers were also used for consumption as vegetable and preparation of chutneys.

The ITK No. 27 and 29 were judged rational and valid because java prepared from ragi \& bajra and gangi prepared from boiled rice are highly nutritious contains vitamins and minerals.

It could be observed from the above Table 2 out of 10 ITKs in Tribal medicine 7 ITKs $(70.00 \%)$ were judged rational by the scientists and 3 ITKs $(30.0 \%)$ were judged not rational whereas only 5 ITKs were found valid.

The ITK No. 1, 2 and 8 were judged rational and valid ITKs because decoction prepared from root tubers of asparagus works as antiseptic agent and the paste prepared from uttareni leaves mixed with camphor acts as good medicine for head ache when applied on forehead.

The ITK No. 7, 9 and 10 were judged rational and valid except ITK No. 7 is not valid. Because the decoction extracted from tephrosia used by tribal women after delivery. The latex of calotropis and uttareni leaves helps in curing dental problem. The ITK No. 4 was judged rational but not valid ITK. For eye infection the juice extracted from lime or onion or fresh turmeric is dropped in the eyes which as medicinal values sometime helps in curing the eye infection but validity are not there.

Indigenous technologies have strong roots in tribal culture. The study reveals that there were nearly 297 ITKs on various crops cultivated in the study area. These ITKs may be documented, tested, verified, standardized for the possibility of blending with modern technologies for profitable and environmental friendly agriculture. The extension personnel while encouraging the continuous use of rational ITKs may suitably educate their clientele to discontinue the irrational ITKs. Farmers were found to have more favourable attitude towards ITKs, hence these can be effectively utilized by the extension personnel in dissemination of information on ITKs. The efforts of different agencies in promotion of ITKs can be effectively utilized in sustainable agriculture.

\section{References}

Ganesamoorthi, S. 2000. Indigenous knowledge on post-harvest practices. M.Sc. (Ag.) Thesis. Tamil Nadu Agricultural University, Coimbatore, India.

Lakshmana, K. 2000. Documentation and Analysis of Indigenous Farm Practices on major crops. An Inventory. M.Sc. (Ag.) Thesis. Tamil Nadu Agricultural University, Coimbatore, India.

Rajasekaran, B. and Whiteford, M.B. 1993. The role of indigenous knowledge in designing food security policies. Food Policy. 18(3): 237-247.

Sundaramari, M and Ranganathan, T. 2003. Indigenous Agricultural Practices for Sustainable Farming/Jodhpur, Agrobios, 311-312.

\section{How to cite this article:}

Praveen, N. and Sreenivasa Rao, I. 2018. Rationality and Validity of ITKs on Tribal Medicine and Tribal Foods of Tribal Farmers in Telangana of Andhra Pradesh, India. Int.J.Curr.Microbiol.App.Sci. 7(10): 2817-2821. doi: https://doi.org/10.20546/ijcmas.2018.710.327 